\title{
Analysis on the Teaching System Structure and Countermeasures of "Ideological and Political Education" in Colleges and Universities
}

\author{
Xia Xin \\ Wuhan Huaxia University of Technology, Wuhan, China, 430223
}

Keywords: Teaching system structure; Course Ideological and political education; Colleges and universities

\begin{abstract}
The ideological and political education is a systematic project, which should adhere to the scientific concept, adhere to the systematic thinking, and promote it by means of detailed planning, design and fruitful practice. This paper analyses the necessity of the construction of "ideological and political education" in colleges and universities in the new era, and probes into the paths from defining the target system of ideological and political work, strengthening the construction of teaching materials, perfecting the construction system of "ideological and political education" and digging deep into the educational resources.
\end{abstract}

\section{Introduction}

The course ideological and political education integrates ideological and political education into all aspects of curriculum teaching, and constructs a complete curriculum education with the function of "explicit ideological politics" and "dominant ideological politics" - ideological and political theory. The course ideological and political education is system engineering with the core of "professional class" ideological and political education, and also the most critical and difficult to solve. Only on the basis of systematic thinking, with the help of scientific design, coordination of various resources, and mobilization of various enthusiasms, can it effectively promote the effective development of this project.

\section{The necessity to construct ideological and political education system}

As General Secretary $\mathrm{Xi}$ Jinping speeches at the National Symposium on Ideological and Political Work in Colleges and Universities, to make full use of the main channels of classroom teaching, it should strengthen the construction of ideological and political theory courses in the process of improvement, and every course should be well maintained, with strong sense of responsibility, so that various courses and ideological and political theory Combine the lessons to improve the quality of teaching, which gave the best evaluation of the concept of "Ideological and Political Education in Curriculum". 


\subsection{Education goals’ inevitable choice}

As a special educational activity, ideological and political education is of great significance to the realization of social progress and the all-round development of people. At present, with the diversification of social values and interests, it is of great significance to carry out ideological and political education for college students and guide them to establish a correct outlook on life and values. But relying solely on ideological and political theory courses and the guidance of ideological and political teachers is not enough. $80 \%$ of university teachers are professional teachers, $80 \%$ of courses are professional courses, and $80 \%$ of students study time for professional study. Therefore, it is urgent to establish a new concept of "curricular ideological and political education", give full play to the advantages of multidisciplinary majors, dig deep into multidisciplinary educational resources, and coordinate with ideological and political theory courses in the same direction. Realize the integration of curriculum and ideological and political education, and jointly achieve educational goals.

\subsection{National rejuvenation's basic requirement}

In the report of the 19th National Congress of the Communist Party of China, General Secretary $\mathrm{Xi}$ Jinping put forward the new requirements of "cultivating new people in the era with the responsibility of national rejuvenation", which pointed out the direction of training socialist talents with Chinese characteristics. In the era of the great rejuvenation of the Chinese nation, the people not only need solid professional knowledge and skills, but also a strong sense of historical responsibility and national sentiments. The fundamental task of colleges and universities is to cultivate and support people. Talent cultivation is inseparable from ideological and political education. "Ideological and Political Courses" embodies the fundamental requirements for building a morality, which is an important way and grasp for the ideological and political education of colleges and universities. In addition, it is a political guarantee for adhering to the direction of socialist education and taking root in world-class universities with Chinese characteristics.

\section{Paths to construct course ideological and political system}

\subsection{Improve ideological and political work position and target system}

In the process of ideological and political construction, it should improve the education system and mechanism with strong educational responsibility, and implement education teaching and diagnosis projects with the help of internal quality education reform and diagnosis construction projects. At the same time, we should strengthen the emphasis on education. To build a "smart campus", we should also strengthen ideological management, campus publicity and guiding education, create a positive and distinctive campus culture. Strengthen the evaluation of teachers' morality and enhance the demonstration role of teachers. Finally, it should strengthen the construction of the school spirit, the integrity education, and the practice of the party's 19th National Spiritual Social Practice, and serve the students for their comprehensive growth and cultivate outstanding builders for the "two hundred years" goal.

\subsection{Strengthen teaching materials construction}

Teaching materials and Textbooks are the important support for educating people and talents, which are the carrier and foundation for the construction of the "Ideological and Political Theory Course" system. All disciplines should thoroughly study the nature of education, such as "teaching 
what" and "how to teach" in order to establish and revise textbooks. The construction of teaching materials must adhere to the guiding position of Marxism and reflect the national will and the value orientation of moral education. At present, the content of the ideological and political course materials is relatively good, but the content is not interesting enough, lack of analysis of the problems that students care about, and lack of readability. It is necessary to strengthen the timeliness of teaching materials, vigorously integrate Xi Jinping's socialist ideas with Chinese characteristics into the textbooks, improve the readability of textbooks, strive to be close to reality, close to students, and easy to understand, and transform ideological and political textbooks into teaching plans and courseware for all teachers, and apply them to other textbooks.

\subsection{Improve the course construction system}

Ideological and political course and management system is the fundamental to implement ideas. Constructing a coherent, coordinated and effective "course ideological and political" management system and operation mechanism is the key to ensure that the concept of "course ideological and political education" could produce practical results. Therefore, it is necessary to establish a management system with clear responsibilities, formulate scientific incentives and constraints and evaluation mechanisms, increase training for teachers, and improve the training mechanism for teachers.

\subsection{Make full use of resources}

It should develop teaching guides and teaching programs, integrate the elements of Ideological and political education in teaching objectives, teaching content, teaching strategies, teaching cases, etc., according to the characteristics of all kinds of courses, to excavate the value, spirit and ideas behind knowledge, and expound them clearly. Give full play to the dominant role of Ideological and political theory course in educating people, pay attention to the value of political culture in educating people, help college students systematically learn the basic knowledge of Marxism, master the methodology of Marxism, and establish a correct world outlook, outlook on life and values.

\section{Countermeasures to conduct ideological and political education}

Teachers and professors of ideological and political theory should play the role of supporters, participate in the planning, design and secondary development of ideological and political courses in the whole ideological and political education system, and pay close attention to the status quo of ideological and political education, and strive to improve the quality of teaching, make timely adjustments to the deviations, help teachers of professional courses to reflect on teaching, and provide theoretical support and answer questions in practical level for them.

Professional teachers should base their own professional strengths and professional cooperation platforms with students to deepen the specific content of ideological and political education and give a thorough explanation. This function and role is also the most necessary for ideological and political education to go deeper and jump out of the doctrine of preaching. The teaching experience and practical wisdom of professional teachers can provide material support and wisdom support for teachers of ideological and political theory. On the practical level, based on the orientation of ideological and political education (and teachers) and ideological and political education courses (and teachers) in professional courses, complementarity and cooperation are realized.

Ideological and political education (and teachers) of professional courses and ideological and political education courses (and teachers) should establish a good cooperative relationship, based on 
the construction and improvement of the course system. Specifically, their cooperation includes not only course planning and design, in-depth development of Ideological and political education content, but also joint development of Ideological and political education resources. As far as course planning and development are concerned, the cooperation between them not only plays an important role in the ideological and political education of professional courses, but also plays a positive role in the reconstruction and innovation of the ideological and political theory course system.

\section{Conclusions}

In summary, colleges and universities should understand the necessity of "course ideological and political education" construction, explore the path of "course ideological and political" construction from all aspects and channels, and pay attention to the integration of professional courses into Ideological and political education, and form a distinctive brand of "course ideological and political education" in order to achieve remarkable results and achieve the desired goals. At the same time, the division and cooperation of Ideological and political courses in professional courses and ideological and political theory courses will bring into full play the function of "ideological and political courses" for professional education in the new era and jointly cultivate the builders of the great cause of national rejuvenation.

\section{References}

[1] Gao Deyi, Zong Aidong From Ideological and Political Course to Course Ideological and Political Course: Constructing the Course System of Ideological and Political Education in Colleges and Universities from a Strategic Perspective [J], Higher education in China, 2017, (1):43-46.

[2] Luo Zhenying. Research on the Quality and Ability Training of College Students from the Perspective of Course Ideology and Politics[J]. Time Education, 2018, (10): 57.

[3] Huang Aibao, Gaoming. Background Analysis of the Construction of "Great Ideological and Political Education" Teaching Model in Colleges and Universities[J]. Journal of China University of Mining and Technology, 2015 (1): 100-105. 